III.-Description of a new Species of Palinurus. By T. W. KIRK, Assistant in the Colonial Museum, Wellington, N. Z.

THE specimen described in this paper was obtained by Mr. J. Buchanan, F.L.S., in December 1877, at Whanigaroa, a small harbour on the west coast of the North Island of New Zealand. Six specimens were captured, but only one preserved; this was placed in the Colonial Museum, and, until lately, bore the label "Palinurus Hugelii, var. tumidus," in the handwriting of Dr. Hector, by whom it has since been intrusted to me for description.

In general appearance this fine species approaches very near $P$. Hugelii from the Indian Ocean. I have, however, carefully compared our specimen with Dr. Heller's description of that species; and it appears to me to possess characters sufficiently distinct to justify its elevation to the rank of a species. I therefore propose to retain Dr. Hector's MS. name, and designate the new species Palinurus tumidus, although, perhaps, giganteus would be more appropriate, the total length from tip of beak to end of telson being 24 inches, the carapace very much swollen and measuring $21 \frac{1}{2}$ inches in circumference.

Dr. Hector informs me that this is the common crawfish at the Sydney market; yet, strange to say, although so large and so common, it does not appear to have been described, the only attempt made to identify it being found in the Sydney Museum, where a specimen bears the label "Palinurus Hugelii?"

\title{
Palinurus tumidus.
}

Carapace beaked, much swollen, armed with very blunt depressed spines, some directed forward, others again standing nearly vertical; a double row of small, stout, blunt spines, standing nearly vertical, runs along the posterior edge of the carapace. Beak stout, round, and curved upwards. Supraorbital spines stout, compressed, turned upwards. Antennal spines stout, somewhat triangular in shape, also turned upwards. Superior antennæ less than the total length of the animal; peduncle armed on its upper and outer surfaces with stout spines. Inferior antennæ smooth, longer than peduncle of superior.

Anterior legs very stout, inferior margin of second joint armed with a row of five or six spines; third joint with a very stout spine at the anterior and another at the posterior extremity, the anterior one being twice the size of the posterior; also a stout triangular spine on the superior distal extremity; fifth joint with a row of six spines on the superior internal angle, the largest and posterior one being directed backwards 
to meet the anterior spine of the third joint, a row of three small blunt spines on the inferior angle. Superior margin of distal extremity of last four pairs of legs armed with a spine.

Abdomen very coarsely granulated and punctate. Tail, especially the telson, armed with small spines; telson rounded at the extremity. Anterior margin of each segment of the abdomen produced into a very prominent spine, backed by three or four teeth.

Whole animal destitute of hair, with the exception of the pedipalps and the inferior surface of the terminal joint of each pair of legs.

Colour reddish brown, tinged in many places with yellow. Length 24 inches; circumference of carapace $21 \frac{1}{2}$ inches.

Distinguished from $P$. Hugelii by its much larger size, by the beak, supraorbital, and antennal spines being turned upwards, by the telson being less triangular, and rounded instead of scarped.

IV.-Additions to the List of New-Zealand Marine Mollusca. By Thomas W. Kirк, Assistant in the Colonial Museum, N.Z.

\section{Dentalium Huttoni, sp. nov.}

Shell white, lustrous; small, curved, rapidly tapering, ribbed, ribs unequal, about eighteen at the anterior end, but diminishing in number towards the apex. Length 63 inch, breadth $\cdot 1$ inch at the anterior end.

Hab. Wellington.

Named after Prof. Hutton, to whose exertions students of conchology in New Zealand are greatly indebted.

Dentalium ecostatum, sp. nov.

Shell white; nearly straight, smooth, gradually tapering; faintly, distantly, transversely striated. Length $\cdot 6$ inch ; breadth 07 inch at the anterior end.

Hab. Waikanae.

Scalaria wellingtonensis, sp. nov.

Shell white, lustrous; acuminate, imperforate; whorls nine, rounded; varices numerous, thin, about seventeen on the body-whorl; interstices smooth; aperture subrotund. Length $\cdot 4$ inch.

Hab. Wellington.

\section{Cylichna zealandica, sp. nov.}

Shell white ; strong, smooth, faintly longitudinally striated; aperture produced above the spire. Length $\cdot 35$ inch.

Hab. Waikanae. 


\section{$2 \mathrm{BHL}$ Biodiversity Heritage Library}

Kirk, T. W. 1880. "III.-Description of a new species of Palinurus." The Annals and magazine of natural history; zoology, botany, and geology 6, 14-15. https://doi.org/10.1080/00222938009458888.

View This Item Online: https://www.biodiversitylibrary.org/item/81219

DOI: https://doi.org/10.1080/00222938009458888

Permalink: https://www.biodiversitylibrary.org/partpdf/63219

\section{Holding Institution}

Smithsonian Libraries

\section{Sponsored by}

Smithsonian

\section{Copyright \& Reuse}

Copyright Status: Public domain. The BHL considers that this work is no longer under copyright protection.

This document was created from content at the Biodiversity Heritage Library, the world's largest open access digital library for biodiversity literature and archives. Visit BHL at https://www.biodiversitylibrary.org. 